\title{
PRESCHOOL PERSONNEL EXPOSURE TO OCCUPATIONAL NOISE
}

\author{
Darja Kalıužnaja ${ }^{1}$ and Svetlana Lakiša ${ }^{2}$ \\ ${ }^{1}$ Department of Occupational and Environmental Medicine, Rīga Stradiṇš University, Dzirciema iela 16, Rīga, LV-1007, LATVIA; \\ darja.kaluznaja@rsu.Iv \\ ${ }^{2}$ Institute of Occupational Safety and Environmental Health, Rīga Stradinš University, Dzirciema iela 16, Rīga, LV-1007, LATVIA \\ \# Corresponding author
}

Communicated by Modra Murovska

\begin{abstract}
Increased noise, which is also below the occupational exposure values and is "hearing safe" noise, affects the exposed person's health as a non-specific stressor. Increased noise level also creates an environment for additional vocal apparatus load. The objective of this study was to determine preschool personnel occupational noise and its relationship with subjective health complaints. Data were obtained with survey assistance through subjective answers of respondents about health complaints and noise exposure among Riga preschool personnel. Objective noise measurements were made to assess real noise levels in the preschool environment. Data from 155 respondents and objective measurements of 37 preschool classrooms were obtained. The results showed that the average 8-h noise exposure among Riga preschool educational institutions was $70 \mathrm{~dB}(A)$, which did not exceed the Latvian work environment noise limits, but exceeded the 35-40 dB(A) noise limit in the educational environment guidelines recommended by the WHO. The survey results showed that loud noise is one of the most important workplace environmental factors ( $70 \%$ of respondents feel a necessity to increase voice because of noise). A constant feeling of fatigue, headache, irritable feeling, and a desire to isolate oneself from others more often occurred in respondents exposed to increased noise, compared with those who noted that they were not exposed to increased noise. In general, loud noise was associated with increased subjective health complaints in preschool education institution personnel.
\end{abstract}

Key words: preschool personnel, noise, health complaints.

\section{INTRODUCTION}

People spend a lot of time at work and work conditions play an important role in providing health and well-being (Kadikis et al., 2008). Physical, chemical, and biological environmental factors can significantly influence the quality of life and cause health disorders. However, it is frequently impossible to measure clearly the health impact of these factors, because the values of their impact are usually low. Those factors affect people throughout their lives and have a long latency period before health problems appear (Anonymous, 2011a).

Teachers' individual professional risk is high — work conditions may cause health complaints. Preschool personnel (preschool teacher and preschool teacher's assistant) divide work duties, but their working conditions are similar, because the entire working time is spent with children (Anonymous, 2012).

The noise level at work should not exceed $87 \mathrm{~dB}(\mathrm{~A})$; nevertheless, even a significantly lower noise level may cause health problems or interfere with execution of work duties.
A limit of $87 \mathrm{~dB}(\mathrm{~A})$ noise at work has been set as a thresfold for hearing impairment reduction (Anonymous, 2003c). Noise can affect peoples' health in two general ways: with hearing-related disorders and with disorders unrelated to hearing. Teachers rarely experience occupational hearing loss, but noise exposure in preschools is associated with increased risk of hearing problems like tinnitus and hyperacusis. Increased hearing impairments and tinnitus were noted by employees in the preschool. Also in the educational environment, communication is impossible even at a level of $80 \mathrm{~dB}(\mathrm{~A})$ noise (normal communication is possible at a noise level below $65 \mathrm{~dB}$ ); high levels lead to increased load of vocal apparatus and associated disorders (Sjödin, 2012; Anonymous, 2003c). Health complaints related to voice apparatus (rapid onset of voice fatigue, incomplete vocal range, and dryness in the throat) are more common for personnel with work experience more than 10 years (Eglite, 2000). Studies have noted that over the past decade schools have changed perceptions of cultural behavior, children have become louder, and as a result teachers have needed increase their voice loudness (Trinite and Sokolovs, 2011; Kankare et al., 2012). Dysphonia (difficulty to speak) 
often occurs in the preschool personnel work environment, because they are working in a room with loud noise, and are very dissatisfied with children' discipline (Bermúdez de Alvear and Martinez- Arquero, 2009). Voice function also depends on the person's psychological well-being. Also, voice problems contribute to a teachers inadvertence to their own health. Untreated upper respiratory tract infections can lead to chronic respiratory disease, which can contribute to the development of voice disorders (Trinite un Sokolovs, 2011). As noise can be as non-specific stressor, employees who experience annoying noise at work, have noted that noise is associated with decreased ability to focus attention on work and worsening memory (Sjödin et al., 2012). Functional changes in the cardiovascular system is a non-specific organism reaction to increased noise; changes can occur if the noise level is more than $60 \mathrm{~dB}(\mathrm{~A})$ (Eglite, 2000; Sjödin et al., 2012). Noise can also contribute to anti-social behavior and cause a variety of complaints. In addition, there can be development of diseases, like an impaired immune system, and thereby reduced resistance to infection and stressrelated headaches, insomnia, irritability, and other psychological changes. Background noise has been identified as a risk factor that may contribute to fatigue, because people increase their voice level when speaking in a noisy environment. Fatigue reduces work ability and concentration to work (Eglìte, 2000).

Preschool education is the beginning of children personality development. It is the time for preparing to school life (Anonymous, 2002), and therefore it is important that at this stage, working conditions of teachers and their assistants allow them use personal potential, creativity and help children to develop, and help them deal with conflicts that arise between children or between a child and parents (Eglite et al., 2008).

The objective of the present study was to estimate preschool personnel occupational noise and determine its relation to subjective health complaints. We examined subjective noise exposure in relation to three groups of subjective health complaints - voice apparatus, physiological, and psychological. The group of voice apparatus subjective complaints included: speaking at a raised voice level, the desire not to speak for some time, hoarseness, loss of voice, and difficulty to speak. The group of physiological health complaints consisted of: dry skin, dry and sore throat, headache, runny or stuffy nose, dry, itchy eyes, sneezing, and coughing. The third group, psychological subjective complaints, included sensitivity, irritability, constant fatigue, desire to isolate from others, anxiety, sleeplessness, depressive feeling, and lack of concentration.

\section{MATERIALS AND METHODS}

The study took place in 11 preschools of Rīga from January to April, 2013. An invitation to participate in the study was sent by e-mail. The study sample was selected using a random sampling method. The general sample was 157 preschools of Riga. From the list of preschools, every fourth was chosen, resulting in invitation letters sent to 39 preschools, of which eleven volunteered to participate in the study. We sent 213 questionnaires, of which 155 (73\%) questionnaires were completed.

The questionnaire was designed at the Institute of Occupational Safety and Environmental Health (Rīga Stradiňš University). The questionnaire included questions about general personal data about the respondent, work experience, subjective health complaints, and physical and psychosocial working environment. The responses were analysed statistically to assess the association between self-reported noise exposure and self-reported health complaints. Health complaints were compared between the exposed group (respondents who answered that they were exposed to a noise level such that they had to raise their voice to speek to others) and non-exposed group (respondents who did not have to raise their voice because of noise to speak to others).

The objective level of noise was measured using stationary noise recordings with a calibrated sound level meter "Cirrus". The recordings were carried out during separate activities: playing time and studying time in each group during one day.

Noise measurements were made in each preschool in four groups with different children age: 3-4 years, 4-5 years, 5-6 years, and 6-7 years. Microphones were mounted at a $\sim 1.6 \mathrm{~m}$ height. A weighted equivalent sound pressure level in $\mathrm{dB}\left(\mathrm{L}_{\mathrm{pAeq}, \mathrm{T}}\right)$ was estimated and the $8 \mathrm{~h}$ noise exposure was calculated to compare results with Latvian regulations.

During the recording, children at preschools were involved in their typical indoor activities. The noise thus came mostly from the children's voices and activities. The teacher voice activity came mostly from comunication with one or several children, that is conversing or instructing, correcting, or encouraging the children in their activities. The software SPSS version 19.0 was used for statistical analyses: descriptive statistics and the chi-square test to test for a statistically significant association between the exposed and non-exposed groups.

\section{RESULTS}

Characteristics of study sample. The questionaries were completed by 155 preschool workers, of which $68.4 \%$ ( $\mathrm{n}=$ 106) were preschool teachers and $31.6 \%(n=49)$ were preschool teacher assistants. All respondents were female. Ages of the participants were: $6.5 \%(\mathrm{n}=10)<$ than 25 years, $17.4 \%(\mathrm{n}=27)$ from 25 to 34 years, $23.2 \%(\mathrm{n}=36)$ from 35 to 44 years, $32.3 \%(\mathrm{n}=50)$ from 45 to 54 years and $20.6 \%(\mathrm{n}=32)>55$ years. $72.3 \%(\mathrm{n}=112)$ of respondents had higher education or unfinished higher education, $15.5 \%$ $(n=24)$ had specialised secondary education, $7.7 \%(n=12)$ had secondary education and $2.6 \%(n=4)$ had primary school education.

Total work experience in preschool in approximately onethird of respondents $(36.1 \%, \mathrm{n}=563)$ was more than 15 


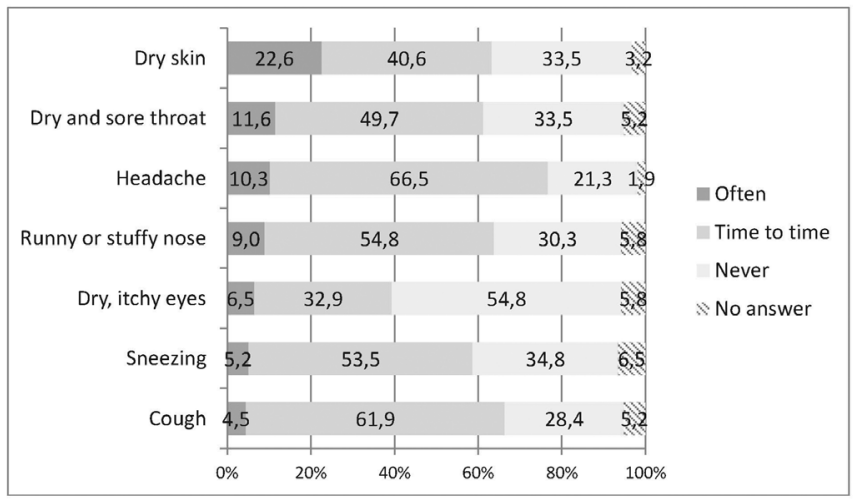

Fig. 1. Physiological health complaints that occur at work during the last month.

years, one-third $(30.3 \%, \mathrm{n}=47)$ had experience $5-15$ years, one-fourth $(23.2 \%, \mathrm{n}=36) 1-5$ years, and the others $(7.1 \%$, $\mathrm{n}=11)$ had started work in the current year. Almost all respondents $(81.3 \%, \mathrm{n}=126)$ had one workplace. Half of the respondents $(49.7 \%, \mathrm{n}=77)$ worked from 31 to 45 hours per week, 23.9\% $(\mathrm{n}=37)$ worked 30 hours (employment rate for preschool personnel in Latvia), 10.3\% $(\mathrm{n}=16)$ for more than 45 hours, and $8.4 \%(n=13)$ worked less than 30 hours.

Respondent health complaints. More than one-third of respondents $(39.3 \%, \mathrm{n}=61)$ had medically confirmed chronical diseases. The most common chronic diseases were: shoulder, neck, back pain $(16.1 \%, \mathrm{n}=25)$, cardiovascular disease $(5.2 \%, \mathrm{n}=8)$, and chronic respiratory disease $(4.5 \%, \mathrm{n}=7)$. The most common self-reported health complaints that respondents felt often or time to time during the last month at work were: headache $(76.8 \%, \mathrm{n}=119)$, cough $(66.4 \%, \mathrm{n}=103)$, runny or stuffy nose $(63.8 \%, \mathrm{n}=99)$, dry skin $22.6 \%(\mathrm{n}=35)$, and dry and sore throat $(11.6 \%, \mathrm{n}=$ 18) (Fig. 1).

To the question "Have you experienced voice problems (loss of voice, hoarseness, voice amplitude changes, etc.) at work?", more than half of the respondents $(69.7 \%, \mathrm{n}=108)$ noted, "Yes" and only $28.4 \%(n=44)$ of respondents had no voice problems. The majority of respondents $(87.1 \%, \mathrm{n}=$ 135 ) were nonsmokers, $3.9 \%(n=6)$ were former smokers, and $11.0 \%(n=17)$ of respondents stated that they smoke.

Voice apparatus-related health complaints that often or time to time had occurred at work during the last month were: necessity to speak louder than the normal speech level $(81.3 \%, \mathrm{n}=126)$, desire not to talk for some time $(76.1 \%, \mathrm{n}$ $=118)$, and hoarseness $(67.1 \%, \mathrm{n}=104)$. Voice loss was less frequent (Fig. 2). Some respondents noted that voice problems more often occurred in the autumn, after the long summer break.

The most common psychological symptoms that often or time to time occurred at work during the previous week were: persistent fatigue, weakness or sleepiness $(72.9 \%, \mathrm{n}=$ $113)$, sensitivity, irritability or nervousness $(67.7 \%, \mathrm{n}=$ $105)$, and difficulty to remember things or in concentrating

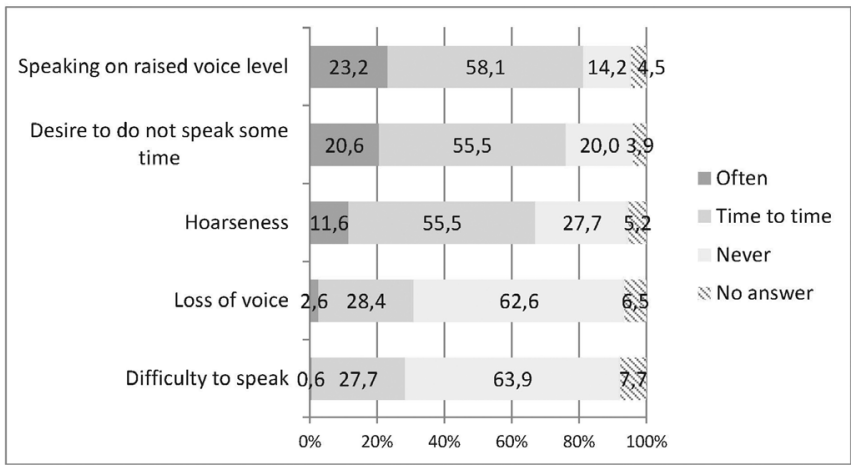

Fig. 2. Voice apparatus health complaints that has occurred at work during the last month.

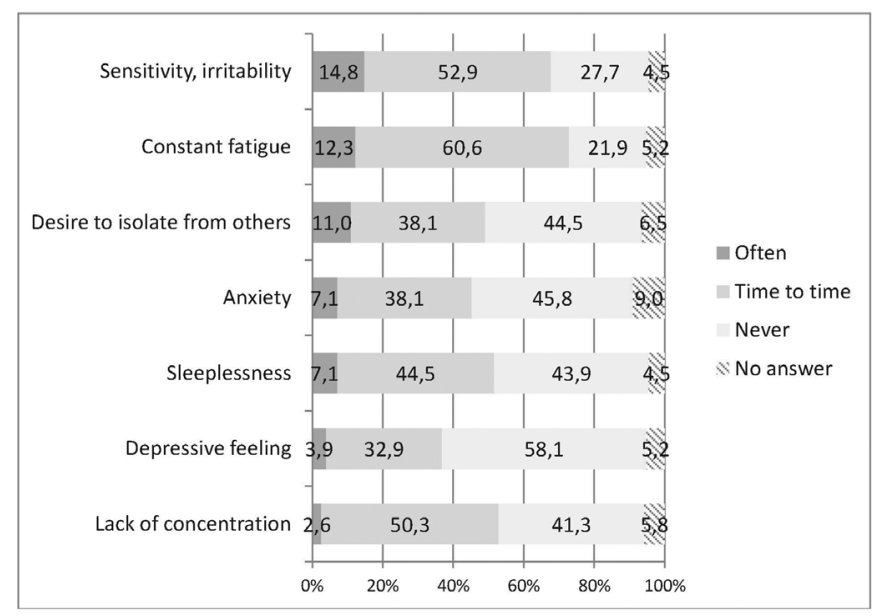

Fig. 3. Psychological health complaints that have occurred at work during the last month.

at work $(52.9 \%, \mathrm{n}=82)$. More than a half of the respondents $(58.1 \%, \mathrm{n}=90)$ never felt depressed (Fig. 3).

Work environment characteristic. Almost all respondents $(80.7 \%, \mathrm{n}=125)$ evaluated their work environment as more than on 5 points (on a 10 point scale). According to the survey results the biggest problem was the necessity to increase voice because of the noise $(69.7 \%, \mathrm{n}=108)$ and classroom microclimate conditions: too dry air $(56.1 \%, \mathrm{n}=$ 87), too high temperature $(46.5 \%, \mathrm{n}=72)$, airless feeling $(45,8 \%, \mathrm{n}=71)$, and low air flow $(44.5 \%, \mathrm{n}=69)$. Background noise as disturbing was mentioned by one-third $(35.5 \%, \mathrm{n}=55)$ of respondents (Fig. 4). Microclimate conditions such as high air temperature and low air relative humidity may indirectly influence the vocal load, because dry air irritates the mucus membranes of the nose and other parts of the upper respiratory system.

Noise. Noise measurements were made in each preschool in four groups with different children age: $3-4$ years, $4-5$ years, 5-6 years. and 6-7 years. The mean number of children in the groups was 14 (from 7 to 21). During playing time, the noise levels were in the range from $66.8 \mathrm{~dB}(\mathrm{~A})$ to $77.6 \mathrm{~dB}(\mathrm{~A})$ and in the studying time from $59.7 \mathrm{~dB}(\mathrm{~A})$ to $76.3 \mathrm{~dB}(\mathrm{~A})$. During playing time, the mean noise levels were similar (about $74 \mathrm{~dB}(\mathrm{~A})$ among different age children 


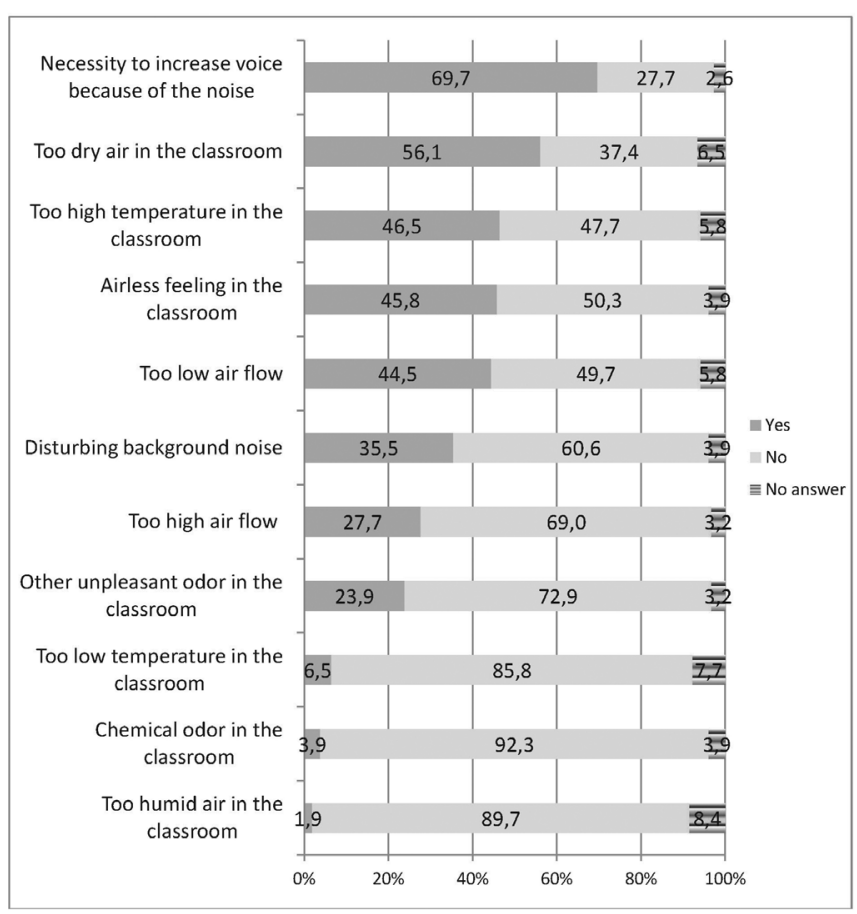

Fig. 4. Were you exposed to different work conditions at work during the last month?

groups, but during studying time the mean noise levels differed ranged from from $66.6 \mathrm{~dB}(\mathrm{~A})$ in the 4-5-year-old children group to $71.1 \mathrm{~dB}(\mathrm{~A})$ in the 3-4-year-old children group (Fig. 5).

The difference between playing time and studying time average noise levels was at least $3 \mathrm{~dB}(\mathrm{~A})$ (respectively: 73.5 $\mathrm{dB}(\mathrm{A})$ and $70.6 \mathrm{~dB}(\mathrm{~A})$ in the 3-4-year-old group; 74.0 $\mathrm{dB}(\mathrm{A})$ and $66.6 \mathrm{~dB}(\mathrm{~A})$ in the 4-5-year-old group; 74.2 $\mathrm{dB}(\mathrm{A})$ and $71.1 \mathrm{~dB}(\mathrm{~A})$ in the 5-6-year-old group; and 74.1 $\mathrm{dB}(\mathrm{A})$ and $67.3 \mathrm{~dB}(\mathrm{~A})$ 6-7-year-old group). This indicated that noise during playing time activities was at least two times louder (based on sound pressure) than during studying time. The mean $8 \mathrm{~h}$ daily noise exposure in different children age groups was about $70 \mathrm{~dB}(\mathrm{~A})$, with the lowest level of $69.4 \mathrm{~dB}(\mathrm{~A})$ in the youngest children groups (3-4 and 4-5 years), the mid level of $69.6 \mathrm{~dB}(\mathrm{~A})$ in the 6-7-year-old children group and the highest level result of $71.3 \mathrm{~dB}(\mathrm{~A})$ in the 5-6-year-old children group. Generally, the noise levels among the different age children groups were similar, but the highest was in the 5-6-year-old children group (Fig. 5).

The difference between playing time and studying time mean noise levels was at least $3 \mathrm{~dB}(\mathrm{~A})$ in the $12-16$ children group, while in the other groups this difference was at least $6 \mathrm{~dB}(\mathrm{~A})$ : $66.6 \mathrm{~dB}(\mathrm{~A})$ and $74.0 \mathrm{~dB}(\mathrm{~A})$ in the 7-11 children group; and $67.7 \mathrm{~dB}(\mathrm{~A})$ and $74.7 \mathrm{~dB}(\mathrm{~A})$ in the $17-21$ children group (Fig. 6). The mean $8 \mathrm{~h}$ daily noise exposure in groups with different children number (7-11 children, 12-16 children and 17-21 children) was about $70 \mathrm{~dB}(\mathrm{~A})$, with a non-significant increase (from $69.0 \mathrm{~dB}(\mathrm{~A})$ to 70.2 $\mathrm{dB}(\mathrm{A})$ ) with increase of number of children in the group. During playing time, the noise was "loudest" in the 17-21

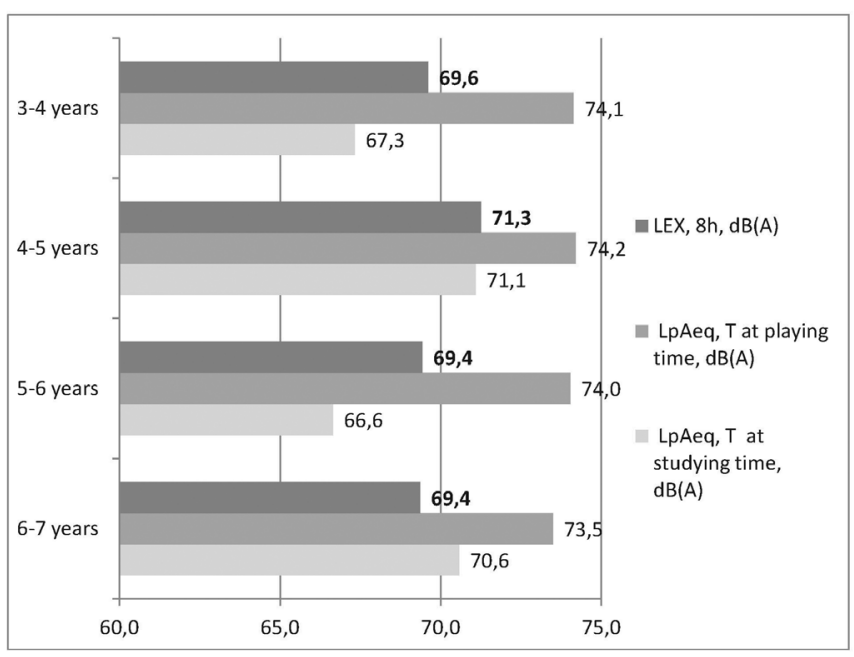

Fig. 5. Leq noise level during studying and playing times and $\mathrm{LEX}_{\mathrm{E}} \mathrm{h}$ in different age children groups, $\mathrm{dB}(\mathrm{A})$.

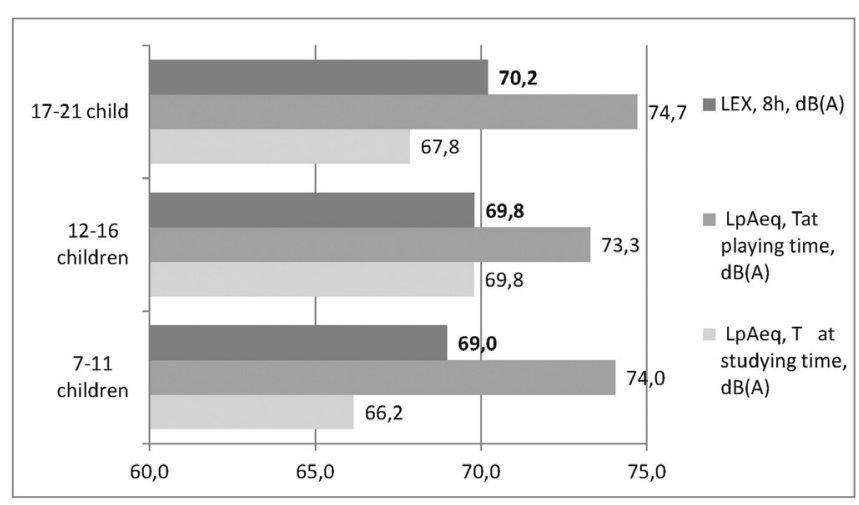

Fig. 6. $\mathrm{L}_{\mathrm{eq}}$ noise level during studying and playing times and $\mathrm{L}_{\mathrm{EX} 8 \mathrm{~h}}$ in different children number groups, $\mathrm{dB}(\mathrm{A})$.

children group $(74.7 \mathrm{~dB}(\mathrm{~A}))$, and the "quietest" in the 12-16 children group $(73.3 \mathrm{~dB}(\mathrm{~A}))$.

Work condition association with health complaints: noise. Health complaints were more frequent in the noise exposed group $(n=108)$ of preschool personnel, who noted that they experienced loud noise at work in the last month, than in the non-exposed group, who noted that they did not experience loud noise at work. The difference between the groups was statistically significant $(p<0.05)$. According to questionnaire results (Table 1), 93.3\% $(n=98)$ of exposed preschool personnel personnel felt the force to speak in a high-pitched tone (compared with 63.4\% $(\mathrm{n}=26)$ in the group who thought that they had no need to raise their voice due to noise), $84.9 \%(n=90)$ of exposed respondents had the feeling that they did not want to speak some time (compared with $63.4 \%(\mathrm{n}=26)$ in the non-exposed group), and $78.7 \%(\mathrm{n}=81)$ exposed respondents had hoarseness of voice (compared with $52.4 \%(\mathrm{n}=22)$ in the non-exposed group) $(\chi 2=10.910, \mathrm{df}=2, p=0.004)$.

$83.3 \%(\mathrm{n}=90)$ of respondents who were exposed to loud noise during last month, often or time to time had a headache (compared with $64.3 \%(\mathrm{n}=27)$ in the non-exposed group) $\left(\chi^{2}=7.008, \mathrm{df}=2, p=0.03\right)$, and $72.2 \%(\mathrm{n}=75)$ of 
NOISE ASSOCIATION WITH VOICE APPARATUS HEALTH COMPLAINTS

\begin{tabular}{|c|c|c|c|c|c|c|c|c|c|c|c|}
\hline \multirow{2}{*}{ Answer } & & \multicolumn{2}{|c|}{ Often } & \multicolumn{2}{|c|}{ Time to time } & \multicolumn{2}{|c|}{ Never } & \multirow{2}{*}{$\begin{array}{l}\text { Total } \\
\text { number }\end{array}$} & \multirow{2}{*}{$\chi^{2}$} & \multirow{2}{*}{ df } & \multirow{2}{*}{$p$} \\
\hline & & $\%$ & number & $\%$ & number & $\%$ & number & & & & \\
\hline \multirow{2}{*}{ Hoarseness } & Exposed & 14.6 & 15 & 64.1 & 66 & 21.4 & 22 & 103 & \multirow{2}{*}{10.910} & \multirow{2}{*}{2} & \multirow{2}{*}{$0.004 *$} \\
\hline & Non-exposed & 4.8 & 2 & 47.6 & 20 & 47.6 & 20 & 42 & & & \\
\hline \multirow{2}{*}{$\begin{array}{l}\text { Desire not to speak for } \\
\text { some time }\end{array}$} & Exposed & 21.7 & 23 & 63.2 & 67 & 15.1 & 16 & 106 & \multirow{2}{*}{8.448} & \multirow{2}{*}{2} & \multirow{2}{*}{$0.015^{*}$} \\
\hline & Non-exposed & 19.5 & 8 & 43.9 & 18 & 36.6 & 15 & 41 & & & \\
\hline \multirow{2}{*}{$\begin{array}{l}\text { Speaking on raised voice } \\
\text { level }\end{array}$} & Exposed & 31.4 & 33 & 61.9 & 65 & 6.7 & 7 & 105 & \multirow{2}{*}{26.242} & \multirow{2}{*}{2} & \multirow{2}{*}{$0.000^{*}$} \\
\hline & Non-exposed & 4.9 & 2 & 58.5 & 24 & 36.6 & 15 & 41 & & & \\
\hline
\end{tabular}

* statistically significant difference between exposed and non-exposed groups

NOISE ASSOCIATION WITH PHYSIOLOGICAL HEALTH COMPLAINTS

\begin{tabular}{|c|c|c|c|c|c|c|c|c|c|c|c|}
\hline \multirow{2}{*}{\multicolumn{2}{|c|}{ Answer }} & \multicolumn{2}{|c|}{ Often } & \multicolumn{2}{|c|}{ Time to time } & \multicolumn{2}{|c|}{ Never } & \multirow{2}{*}{$\begin{array}{c}\text { Total } \\
\text { number }\end{array}$} & \multirow{2}{*}{$\chi^{2}$} & \multirow{2}{*}{ df } & \multirow{2}{*}{$p$} \\
\hline & & $\%$ & number & $\%$ & number & $\%$ & number & & & & \\
\hline \multirow{2}{*}{ Headache } & Exposed & 10.2 & 11 & 73.1 & 79 & 16.7 & 18 & 108 & \multirow{2}{*}{7.008} & \multirow{2}{*}{2} & \multirow{2}{*}{$0.030^{*}$} \\
\hline & Non-exposed & 11.9 & 5 & 52.4 & 22 & 35.7 & 15 & 42 & & & \\
\hline \multirow{2}{*}{ Dry and sore throat } & Exposed & 13.5 & 14 & 58.7 & 61 & 27.9 & 29 & 104 & \multirow{2}{*}{10.206} & \multirow{2}{*}{2} & \multirow{2}{*}{$0.006^{*}$} \\
\hline & Non-exposed & 7.3 & 3 & 36.6 & 15 & 56.1 & 23 & 41 & & & \\
\hline
\end{tabular}

* statistically significant difference between exposed and non-exposed groups

Table 3

WORKING CONDITIONS IN RELATION TO PSYCHOLOGICAL HEALTH COMPLAINTS

\begin{tabular}{|c|c|c|c|c|c|c|c|c|c|c|c|}
\hline \multirow{2}{*}{ Answer } & & \multicolumn{2}{|c|}{ Often } & \multicolumn{2}{|c|}{ Time to time } & \multicolumn{2}{|c|}{ Never } & \multirow{2}{*}{$\begin{array}{c}\text { Total } \\
\text { number }\end{array}$} & \multirow{2}{*}{$\chi^{2}$} & \multirow{2}{*}{ df } & \multirow{2}{*}{$p$} \\
\hline & & $\%$ & number & $\%$ & number & $\%$ & number & & & & \\
\hline \multirow{2}{*}{ Persistent fatigue } & Exposed & 13.5 & 14 & 70.2 & 73 & 16.3 & 17 & 104 & 10.584 & 2 & $0.005^{*}$ \\
\hline & Non-exposed & 12.2 & 5 & 46.3 & 19 & 41.5 & 17 & 41 & & & \\
\hline \multirow{2}{*}{ Sensitivity, irritability } & Exposed & 20.2 & 21 & 55.8 & 58 & 24.0 & 25 & 104 & 8.182 & 2 & $0.017 *$ \\
\hline & Non-exposed & 4.8 & 2 & 52.4 & 22 & 42.9 & 18 & 42 & & & \\
\hline \multirow{2}{*}{$\begin{array}{l}\text { Desire to isolate from } \\
\text { others }\end{array}$} & Exposed & 12.6 & 13 & 47.6 & 49 & 39.8 & 41 & 103 & 11.105 & 2 & $0.004 *$ \\
\hline & Non-exposed & 10.0 & 4 & 20.0 & 8 & 70.0 & 28 & 40 & & & \\
\hline
\end{tabular}

*statistically significant difference between exposed and non-exposed groups

exposed respondents had sore, dry throat (compared with $43.9 \%(\mathrm{n}=18)$ in the non-exposed group) $\left(\chi^{2}=10.206\right.$, df $=2, p=0.006)$ (Table 2).

Table 3 shows that $83.7 \%(n=87)$ of respondents who experienced a loud noise level, often or time to time had persistent fatigue, weakness or sleepiness (compared with $58.5 \%(n=24)$ in the non-exposed group). Sensitivity, irritability or nervousness was experienced by $76.0 \%(n=79)$ respondents in the exposed group, compared with $57.2 \%$ $(\mathrm{n}=24)$ in the non-exposed group, and 60.2\% $(\mathrm{n}=62)$ respondents in the exposed group had a desire to isolate from others (compared with 30.0\% $(\mathrm{n}=12)$ in the non-exposed group) $\left(\chi^{2}=11.105\right.$, df $\left.=2, p=0.004\right)$.

\section{DISSCUSION}

In the two groups (exposed to noise group and control group), the most common health complaints were that they felt the force to speak in a high-pitched tone $(93.3 \%$ versus $63.4 \%)$, the desire not to speak for some time ( $84.9 \%$ versus $63.4 \%)$, and hoarseness $(78.7 \%$ versus $52.4 \%)$. Noise at work may contribute to voice problems, since people increase their voice level when speaking in a noisy environment (Lindstrom et al., 2011). In a study in Sweden, $80 \%$ teachers agreed with the statement that during the day they feel a necessity to raise voice. Also, in that study, $87 \%$ of teachers who answered that they did not experience a voice problem, still reported a combination of symptoms, but with 
a lower frequency, such as throat clearing, hoarseness, and voice change, which were clinically considered to constitute a voice disorder (Åhlander et al., 2011).

Noise that is loud enough to require raising one's voice may be a objective parameter, because in a typical classroom situation it has been reported that teachers spoke at the speech level on average 15-16 $\mathrm{dB}(\mathrm{A})$ higher than the background noise; if noise in the classroom was about $55 \mathrm{~dB}(\mathrm{~A})$, the teacher's voice level was about $70 \mathrm{~dB}(\mathrm{~A})$, which provides $95 \%$ of speech intelligibility within the range of one meter (Södersten et al., 2002). Normal conversation sound levels fluctuate around $65 \mathrm{~dB}$ and if person raises his/her voice the sound level may reach $80 \mathrm{~dB}$. The difference is only $15 \mathrm{~dB}$, but the raised voice sound level intensity is 30 times bigger (Anonymous, 2013). In the Swedish study, preschool teacher individual sound pressure levels ranged from 64 to $72 \mathrm{~dB}(\mathrm{~A})$, while the voice sound pressure levels were from 71 to $79 \mathrm{~dB}(\mathrm{~A})$, which means that the mean level of background noise was lower than the voice sound level by $7 \mathrm{~dB}(\mathrm{~A})$. Voice usage by different preschool teachers differs, as one may choose to speak louder than the background noise, while another prefer not to do so; the vocal behaviour in relation to noise exposure is highly individual (Lindstrom et al., 2011). In a Brazilian study, approximately $25 \%$ of educators had a normal voice level and $75 \%$ altered their voice in the auditorium (Simões-Zenari et al., 2009).

Nevertheless, a large majority of the respondents $(69.7 \%)$ noted that their career was associated with voice problems (such as loss of voice, hoarseness, and voice changes in altitude). Also, in a study in Spain, $62.7 \%$ of teachers during their career time had voice problems. Hoarseness was more often noted by female teachers who worked in preschools, where there were higher noise levels than in schools. Preschool teachers also showed delayed vocal recovery, increased absenteeism, and more health service demands (Bermúdez de Alvear and Martinez-Arquero, 2009). Vocal abuse is frequently mentioned as a causal factor for developing functionally based vocal disorders such as vocal fatigue and vocal nodules. These diagnoses are common in female preschool teachers who seek medical help due to their voice problems (Södersten et al., 2002).

In the present study, only $47.1 \%$ respondents did not feel sick and could fulfil their daily work without obstacles. The most common preschool personnel health complaints at work during the previous month were headache $(76.8 \%)$, cough $(66.4 \%)$, and runny or stuffy nose $(63.8 \%)$. Similarly, in a study conducted in the Republic of Bashkortostan, headache was reported by $80 \%$ teachers $(30 \%$ of whom had headache at work at least once a week) and wet cough by $40 \%$ teachers (more often it occurred during the cold season, when they left a warm room, and vice versa) (Stepanov et al., 2010). The most common health complaints in the exposed and non-exposed group were headache $(83.3 \%$ vs $64.3 \%)$ and sore, dry throat (72.2\% vs $43,9 \%)$. Every tenth $(8.3 \%)$ Latvian resident complains about headache and im- pairment of memory associated with the working environment and conditions (Anonymous, 2007).

A high level of noise (even if it is lower than the occupational standard) interferes in communication and partly blocks person's attention and concentration, inhibits memory, and contributes to the occurence of stress and excessive fatigue (Simões-Zenari et al., 2009). However, parents expect that preschool teachers will remain calm even in situations of stress and high noise level.

The psychological health complaints that showed the largest differences in occurrence between the noise-exposed respondent group and control group were: persistent tiredness, weakness or sleepiness ( $83.7 \%$ vs $58.5 \%)$, sensitivity, irritability or nervousness (76.0\% vs $57.2 \%$ ), and the desire to isolate from others $(60.2 \%$ vs $30.0 \%)$. Teachers complained about the difficulty of being heard and understood in noisy environments. In a study conducted in Sweden, the most common health complaints were fatigue, headache, and neck/shoulder pain (Sjödin et al., 2012). In Germany, it was reported that $67.5 \%$ of the teachers were annoyed by high sound levels and that $30 \%$ felt fatigue every day, except on the weekend, and also that $81.3 \%$ of older teachers considered it more demanding to cope with noise today than at the beginning of their professional activity, whereas only $44 \%$ of the younger teachers rated noise today as being harder than at the beginning. $90 \%$ of teachers who were employed full-time noted that the noise level was higher in the evening than in the morning (Eysel-Gosepath et al., 2012).

Preschool teachers need to focus their attention on children's activities all the time and communicate as well. To avoid fatigue, nervousness, and restlessness, which may be caused by permanent noise, it is recommended not to exceed $65 \mathrm{~dB}(\mathrm{~A})$ limits in mental work (Lindstrom, 2011; Anonymous, 2003b). In the guidelines it is recommended not to exceed noise levels 35-45 $\mathrm{dB}(\mathrm{A})$ in educational institutions (Anonymous, 2003a; Anonymous, 2016). Estimated mean noise levels $\mathrm{L}_{\mathrm{Aeq}}$ in Sweden were reported to be 63 $\mathrm{dB}(\mathrm{A})$ by Sjödin et al. (2012) and $76.1 \mathrm{~dB}(\mathrm{~A})$ by Södersten et al. (2002).

It is important to bear in mind that our study in preschools of Rīga took place during the cold season, when many children were sick, which may have decreased the level of noise. The groups consisted of a mean number of 14 children (minimum 7, maximum 21). Noise measurements were made in four children age groups in each preschool. The average $8 \mathrm{~h}$ noise exposure level was $70 \mathrm{~dB}(\mathrm{~A})(\mathrm{SD}=2.95$, minimum $=60.8 \mathrm{~dB}(\mathrm{~A})$, maximum $=73.8 \mathrm{~dB}(\mathrm{~A})$ ). According to the regulations of Latvian Cabinet of Ministers No. 66 , in work conditions where $\mathrm{L}_{\mathrm{EX}}, 8 \mathrm{~h} 80 \mathrm{~dB}(\mathrm{~A})$, employees must be provided with personal hearing protection (Anonymous, 2003c). The current occupational limits were established for prevention of hearing impairment. This raises the question: can preschool noise be compared with industry noise? And also, whether there are other unwanted health effects of noise exposure below the occupational limits. In 
preschools of Riga, the noise level was measured during playing time and studying time. The mean $\mathrm{L}_{\text {Aeq }}$ during studying time was $68.4 \mathrm{~dB}(\mathrm{~A})(\mathrm{SD}=4.34)$ and during playing time $-74.4(\mathrm{SD}=2.96)$. The difference in mean $\mathrm{L}_{\mathrm{Aeq}}$ between studying and playing times was at least $3 \mathrm{~dB}(\mathrm{~A})$ for all age groups of children, i.e. noise during playing time was at least twice louder (estimated by sound pressure) than during studying time. Overall, the noise level did not differ much among the age groups, excepting higher levels in the 5-6-year-old children group. Children adapt to the preschool environment, became more confident about themselves and may cooperate with other children and make more noise than separately. Among these, children at the age of 6-7 years are preparing for school life, and teachers may put greater emphasis on discipline. As children's age increases, they have fewer emotional and behavioural problems (Vahedi et al., 2012), which could potentially reduce the noise from crying or teacher reprimands.

Mean noise level LAeq in groups with different number of children (7-11, 12-16, and 17-21) was $70 \mathrm{~dB}(\mathrm{~A})$ during studying time and $74 \mathrm{~dB}(\mathrm{~A})$ during playing. In a previous study in schools, the average noise $\mathrm{L}_{\mathrm{pAeq}}$ during the break between lessons was $83 \mathrm{~dB}(\mathrm{~A})$ (Stepanov et al., 2012). During the break between lessons, noise is produced by more children (from many classes). The acoustics in school buildings may differ from that in preschools, and at schools a high level noise occurs for a shorter time than in preschools where it is almost constantly high. The difference in noise level between playing and studying times was at least 3 $\mathrm{dB}(\mathrm{a})$ in the 12-16 children group, while in the other groups the difference was at least $6 \mathrm{~dB}(\mathrm{~A})$. This means that playing time activities are four times louder (in sound pressure) than studying activities. A large European study reported that noise increases with increasing number of children in the class, leading to greater load on the teachers' voice apparatus (Anonymous, 2011b; Fredrik Sjödin Sjödin et al., 2012).

In the present study, the loudest group was not the largest group with higher number of children, but with 12-16 children. Noise levels are unsustainable in preschool group during the day, they differ between playing time and studying time and noise caused by children depends on many other factors: children's mood, interpersonal relationships, plan of daily activities for the group, also on the teacher's position and authority. Besides the physically based effect of the number of children on the noise level, in preschool, noise levels also may be affected by behavioural effects. Some teachers noted that within an age group, behaviour differs between years; there may be "quiet" years (children born in a similar year), and "loud" years.

The estimated noise levels are representative of the noise levels at Latvian preschools that are experienced by preschool personnel. In general, subjective experiences of noise in direct and indirect way increase subjective health complaints in preschool education institution personnel.

\section{REFERENCES}

Anonymous (2002). Latvijas Republikas Saeima. Izglítības likums [Parliament of the Republic of Latvia. Law of Education] (30 May 2002). Available at:

http://www.likumi.lv/doc.php?id=50759 (accessed 30 September 2016) (in Latvian).

Anonymous (2003a). Ar darba vides troksni saistìto risku novērtēšanas un novēršanas vadlīnijas [Guidelines to Assessment and Prevention of Risk Caused by Work Environment Noise]. (2003). Labklājības ministrija, Rìga. 47 lpp. (in Latvian).

Anonymous (2003b). Darba apstākḷu novērtēšana mazajos un vidējos uznēemumos [Assesment of Working Conditions in Small and Medium-Sized Enterprises]. Labklājības ministrija, Rīga (in Latvian). 153 lpp.

Anonymous (2003c). Latvijas Republikas Ministru kabinets. Noteikumi Nr. 66 "Darba aizsardzības prasības nodarbināto aizsardzībai pret darba vides trokšna radīto risku" [Cabinet of Ministers of the Republic of Latvia. Regulations No. 66 "Requirements of Occupational Health to Protect Employees From Risk of Occupational Noise"] (4 February 2003). Latvijas Vēstnesis, 8 February 2003 (in Latvian).

Anonymous (2005). Latvijas Republikas Ministru kabinets. Noteikumi Nr. 527 "Kārtība, kādā veicama obligātā veselības pārbaude" [Cabinet of Ministers of the Republic of Latvia. Regulations No. 525 "Procedure of Carying Out Manditory Health Inspection"] (8 June 2004). Latvijas Vēstnesis, 19 August 2005 (in Latvian).

Anonymous (2007). Darba apstākḷi un riski Latvijā [Working Conditions and Risks in Latvia]. Available at:

http://www.1m.gov.1v/upload/darba_tirgus/darba_aizsardziba/ darba_apstakli_un_riski_latvija.pdf (accessed 30 September 2016) (in Latvian).

Anonymous (2011a). Latvijas Republikas Ministru kabinets. Rīkojums Nr. 504 "Sabiedrības veselības pamatnostādnes 2011.-2017. gadam" [Cabinet of Ministers of the Republic of Latvia. Regulations No. 504 "Public Health Strategy for 2011-2017'] (5 October 2011). Available at: http://www.vm.gov.lv (in Latvian).

Anonymous (2011b). Teachers' Work-Related Stress: Assessment, Comparison and Evaluation of the Impact of Psychosocial Hazards on Teachers at Their Workplace. European Trade Union Committee for Education Project's Survey. Brussels. 26 pp.

Anonymous (2012). Profesiju aprakstu katalogs. Profesionālās karjeras izvēles valsts aǵentūra. [Catalogue of profession description. Professional Career Counseling State Agency]. Available at:

http://www.nva.gov.lv/karjera/docs/profesiju_aprakstu_katalogs_A4.pdf (accessed 30 September 2016) (in Latvian).

Anonymous (2013). Trokšņa iedarbība darba laikā. Eiropas Darba drošǐbas un veselības aizsardzības aǵentūra [Noise Exposure at Work. European Agency for Safety and Health at Work]. Available at:

https://osha.europa.eu/lv/tools-and-publications/publications/factsheets/57 (accessed 30 September 2016) (in Latvian).

Anonymous (2016). Guidelines for Community Noise. World Health Organization. Available at:

http://www.who.int/docstore/peh/noise/guidelines2.html (accessed 30 September 2016).

Åhlander, V. L., Rydell, R., Löfqvist, A. (2011). Speaker's comfort in teaching environments: Voice problems in Swedish teaching staff. J. Voice, 25, 430-440.

Berg-Nielsen, T. S., Solheim, E., Belsky, J., Wichstrom, L. (2012). Preschoolers' psychosocial problems: In the eyes of the beholder? Adding teacher characteristics as determinants of discrepant parent-teacher reports. Child Psychiatry Hum. Dev., 43, 393-413.

Bermśdez de Alvear, R., Martinez-Arquero, G. (2009). Teachers' voice disorders collateral effects. Otorynolaryngologia, 8 (3), 129-135.

Eglīte, M. (2000). Darba medicīna [Occupational Medicine]. Rīgas Stradiṇa universitāte, Rīga. 856 lpp. (in Latvian).

Eglīte, M., Baķe, M. Ā., Dundurs, J. (2008). Vides veselība [Environmental Health]. Rīgas Stradiṇa universitāte, Rīga. 696 lpp. (in Latvian). 
Eysel-Gosepath, K., Daut, T., Pinger, A., Lehmacher, W., Erren, T. (2012). Effects of noise in primary schools on health facets in German teachers. Noise Health, 14, 129-134.

Kadik̦is, N., Muceniece, S., Šnepste, M. (2008). Latvijas iedzīvotāju aptaujas rezultāti. Vides faktoru ietekme uz veselību [Impact of Environmental Factors on Health]. Sabiedrības veselības aǵentūra, Rīga. 67 lpp. (in Latvian).

Kankare, E., Geneid, A., Laukkanen, A. M. Subjective evaluation of voice and working conditions and phoniatric examination in kindergarten teachers. Abstract. Available at:

https://www.ncbi.nlm.nih.gov/pubmed/21734396 (accessed 30 September 2016).

Lindstrom, F., Waye, K. P., Södersten, M., McAllister, A., Ternström, S. (2011). Observations of the relationship between noise exposure and preschool teacher voice usage in day-care center environments. J. Voice, 25, 166-172.

Simões-Zenari, M., Bitar, M. L., Nemr, N. K. (2009). The effect of noise on the voice of preschool institution educators. Rev. Saude Publica, 46 (4). Available at:

http://www.scielosp.org/scielo.php?pid=S0034-89102012000400010\&sc ript=sci_arttext\&tlng=en (accessed 30 September 2016).

Sjödin, F., Kjellberg, A.,Knutsson, A., Landström, U., Lindberg, L. (2012). Noise exposure and auditory effects on preschool personnel. Noise Health, 14, 72-82.

Received 15 September 2016
Sjödin, F., Kjellberg, A., Knutsson, A., Landström, U., Lindberg, L. (2012). Noise and stress effects on preschool personnel. Noise Health, 14, 166-178.

Södersten, M., Granqvist, S., Hammarberg, B., Szabo A. (2002). Vocal behavior and vocal loading factors for preschool teachers at work studied with binaural DAT recordings. J. Voice, 16 (3), 356-371.

Trinīte, B., Sokolovs, J. (2011). Balss traucējumus izraisošie riska faktori pedagogiem [Risk Factors of Voice Disorders in Teachers]. Grām.: Latvijas Universitātes raksti. 759. sēj. Latvijas Universitāte, Rīga, 101.-111. 1pp. (in Latvian).

Vahedi, S., Farrokhi, F., Farajian, F. (2012). Social competence and behavior problems in preschool children. Iran J. Psychiatry, 7, 126-134.

Stepanov, J. G., Ishmukhametov, I. B. (2012). Evaluating Individual Occupational Risk in Teachers [Степанов, Е. Г., Ишмухаметов, И. Б. Оценка индивидуального профессионального риска учителей]. Medicina truda $i$ promishlennaya ekologiya [Медицина труда и промышленная экология], 1, 39-41 (in Russian).

Stepanov, J. G., Fasikov, R. M., Didenko, N. A., Akimova, V. S., Ishmukhametov, I. B. (2010). Work and Health of Comprehensive School Teachers Nowadays [Степанов, Е. Г., Фасиков, Р. М., Диденко, Н. А., Акимова, В. С., Ишмухаметов, И. Б. Труд и здоровье учителей общеобразовательных школ в современных условиях]. Medicina truda $i$ promishlennaya ekologiya [Медицина труда и промышленная экология], 6, 24-27 (in Russian).

\section{PIRMSSKOLAS IZGLĪTĪBAS IESTĀDES DARBINIEKU EKSPOZĪCIJA DARBA VIDES TROKSNIM}

Pētījumi liecina, ka paaugstināts troksnis, kas ir zemāks par arodekspozīcijas darbības vērtībām un ir "dzirdei drošs", var ietekmēt balss aparātu un nervu sistēmu. Pētījuma mērḳis bija izpētīt pirmsskolas izglìtības iestāžu (PII) darbinieku darba vides troksni un tā saistību ar subjektīvām veselības sūdzībām. Pētījuma dati tika iegūti no objektīviem mērījumiem un nodarbināto aptaujām, tika analizēta trokšņa izplatība un subjektīvās veselības sūdzības Rīgas PII darbiniekiem. Kopumā tika iegūti aptauju dati no 155 respondentiem un objektīvo mērījumu rezultāti no 37 PII bērnu grupu telpām. Pētījuma rezultāti parāda, ka Rīgas pirmsskolas izglītības iestāžu, kuras ir piedalījušās pētījumā, trokšņa vidējā ekspozīcijas vērtība 8 stundām ir $70 \mathrm{~dB}(\mathrm{~A})$, kas nepārsniedz Latvijas darba vides trokšņa normatīvus, bet pārsniedz vadlīnijās ieteicamo 35-40 dB(A) troksni mācību vidē. Skaḷu troksni pirmsskolas izglītības iestādes darbinieki atzīmē kā būtiskāko darba vides risku. Pastāvīga noguruma sajūtu, galvassāpes, aizkaitināmības sajūtu un vēlmi izolēties biežāk izjūt paaugstinātam troksnim pakḷautie PII darbinieki, salīdzinot ar tiem, kuri to neatzīmē. No pētījuma var secināt, ka paaugstināts troksnis palielina subjektīvas veselības sūdzības pirmsskolas izglītības iestāžu darbiniekiem. 